\title{
Groundwater Recharge and Precipitation as Major Cause of Soil and Gully Erosion in Lafia Town and Environs of Nassarawa State
}

\author{
Nwabineli Emmanuel Onochie ${ }^{1,}$ Ogonna Nwokoye ${ }^{2}$, Dr C.O.C Awalla ${ }^{3}$ \\ ${ }^{I}$ Department of Ceramic and Glass Technology, Akanilbiam Federal Polytechnic, Unwana, Ebonyi State., \\ ${ }^{2}$ Department of Civil Engineering, Federal Polytechnic, Oko, Anambra State. \\ ${ }^{3}$ Department of Geology and mining Enugu State University of science and technology, Enugu State.
}

\begin{abstract}
Aquifer parameters such as groundwater recharge, precipitation were investigated and put through mathematical analyses, direct field measurement of rainfall and climate data from the archive of the Nigerian Meteorological Services Agency were consulted.,. Results showed that the region have high vulnerability to climate variations with significant variation rainfall $(406 \mathrm{~mm})$ over the years. Similarly the region experienced widespread inundation soon after every rain event.. The investigation reveals that Rainfall leads to runoff which is the central agent in the soil erosion system in the region. Also the nature of the earth materials and subsurface lithology was studied,which explains the distribution of gullies in the region. It was discovered that the area is made up of loose, highly permeable, less cohesive sand with high rate of groundwater discharge and as such yield easily to gully erosion. Ground water recharge was calculated and thevalues range from $305 \mathrm{~mm} / \mathrm{yr}(17 \%$ of precipitation) at Awe Formation, and $418.9 \mathrm{~mm} / \mathrm{yr}$ ( $21 \%$ of precipitation ) in Lafia sands Formation . The Lafia sandstone registers the highest amount of groundwater recharge because it consists of principally porous and clean sands. The Aweshaleshas the lowest because of the less permeability of the shales. Run-off is high, due to rapid population growth and associated agricultural practice that deprive the soil surface of its vegetation cover.
\end{abstract}

Keywords:- Gully erosion, run-off, groundwater recharge, precipitation.

\section{INTRODUCTION}

Soil erosion and gullying are common phenomena that ravaging the landscape of the area. The dominant agent of gullying is water. There are two factors influencing gully erosion development in the study area. They are physical and human factors. The physical factors include climate, earth materials and gradient. The human factors are connected with mostly agricultural practices and other land uses.

Rainfall is an important physical factor and its effects depend on the amount and intensity, diameter and the velocity of fall of the drops. When the drops strike the soil, the kinetic energy of the drops is used to loosen the soil particles. Where there is poor vegetation covers, infiltration could lead to problems of landslide, mass wasting, subsidence and slumping. Rainfall leads to runoff which is the central agent in the soil erosion system. Unconcentrated runoff gives rise to "sheet wash" (sheet erosion) while concentrated runoff leads to gullying under favourablelithologic and gradient conditions. It is the nature of the earth materials and subsurface lithology that explains the distribution of gullies in the region. The main gullies are, thus, concentrated on the Lafia East, Doma flank, Keana region, Ricemill area, Obi and Awe areas. The area is made up of loose, highly permeable, less cohesive sand and as such yield easily to gully erosion. The surface configuration (slope and relief) aids runoff, sheet erosion, and gullying. Many factors controls groundwater recharge like soil texture and composition. A loose porous/permeable sandy soil has high infiltration capacity. In layered soils, the transmission capacity of each layer determines the overall infiltration rate. Typically, a bare sandy soil has infiltration capacity of $1.2 \mathrm{~cm} / \mathrm{hr}$ while bare clay has $0.15 \mathrm{~cm} / \mathrm{hr}$ (Subramanya, 1994) though clay is porous, clay mineral absorbs water, swell and block these pores, rendering clays less permeable. 
Precipitation over the area is in the form of rainfall (Table 1)

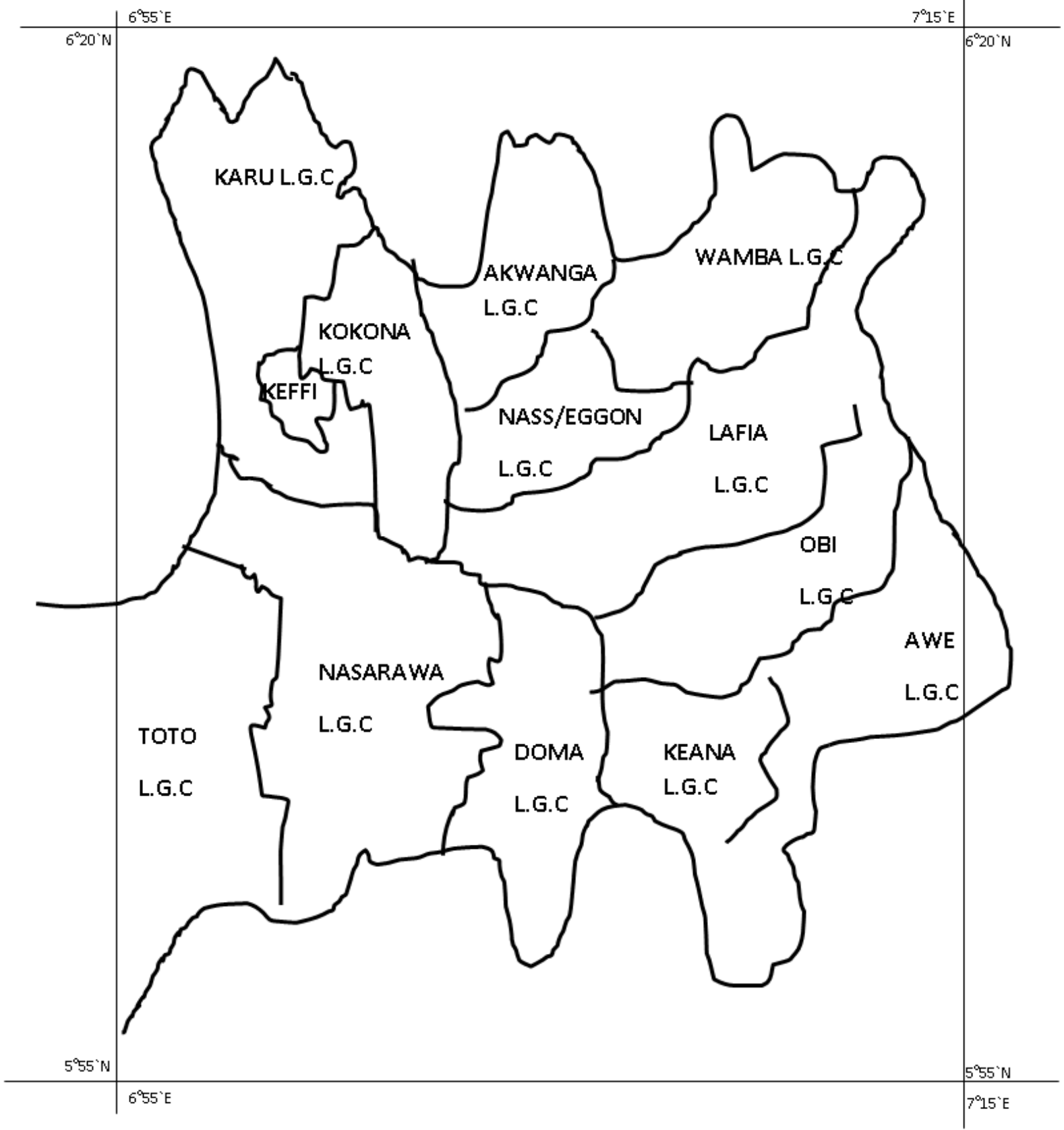


Table 1 Average yearly Rainfall in Lafia/Doma Area for the past 11 years.

\begin{tabular}{|c|c|c|c|c|c|c|c|c|c|}
\hline \multirow{2}{*}{$\begin{array}{l}\text { Formation } \\
\text { Metecrological. } \\
\text { station }\end{array}$} & \multicolumn{2}{|c|}{ Lafia Sand 8} & \multicolumn{2}{|c|}{ Awe Shale } & \multicolumn{2}{|c|}{ Keana Formation } & \multicolumn{2}{|c|}{ Ezealar/Maluurdi } & \multirow[b]{2}{*}{ Yearly Average } \\
\hline & Onaje & $\begin{array}{l}\text { Lafia } \\
\text { farm }\end{array}$ & Dedere & AgwanTw & $\begin{array}{l}\text { Adoka } \\
\text { forestyy }\end{array}$ & Ogugu & Dekine & $\begin{array}{l}\text { Doma } \\
\text { Agricultural } \\
\text { Settlement }\end{array}$ & \\
\hline 1985 & 1705.2 & 1940.5 & & & 1594.7 & 1927.5 & 1823.2 & 2317.7 & $11308.8 / 1884.8$ \\
\hline 1986 & 1007.7 & 1628.2 & & & 1368.1 & 1471 & 911.37 & 1935.6 & $8322 / 1380.7$ \\
\hline 1987 & 1526.9 & 1705.3 & & & 1226.4 & 1475 & 1065 & 2163.9 & $9160.5 / 1526.6$ \\
\hline 1988 & \begin{tabular}{|l}
1658.1 \\
\end{tabular} & 2004.9 & & & 1584.3 & 1755 & 1972.2 & 1910 & $10883.7 / 1313.95$ \\
\hline 1989 & 1761.3 & 1942.5 & & & 1616.7 & 1478.7 & 1305.5 & 2259.4 & $10364.3 / 1227.4$ \\
\hline 1990 & 2049.1 & 2115.4 & & & 1449.4 & 2037.9 & 1608.8 & 2774 & $12034.6 / 2005.8$ \\
\hline 1991 & 2287.5 & 1138.3 & 1833.7 & & 1869.6 & 1525.1 & 1851.2 & 2880.2 & $13385.7 / 1712.2$ \\
\hline 1992 & 1902 & 1408.3 & 1640.8 & & 1813.8 & 1722.1 & 2020.3 & 2131.9 & $12639.2 / 1305.6$ \\
\hline 1993 & 1990 & 1001.7 & 1611.8 & 2130.9 & 1524.6 & 1877.4 & 1372.9 & 1621.8 & $1313.1 / 1641.4$ \\
\hline 1994 & 2407.5 & 1552.8 & 1857.3 & 1656.6 & 1987.7 & 1709.7 & 2216.4 & 1960.7 & $15348.7 / 1918.6$ \\
\hline 1995 & 2150.5 & & 1945.9 & 1644.2 & 1866.9 & 2062.7 & 3474.2 & 21955.7 & \\
\hline $\begin{array}{l}\text { Area Totals } \\
\text { Averages }\end{array}$ & \begin{tabular}{|l|}
$20445.8 /$ \\
1858.7
\end{tabular} & $\begin{array}{l}16437.6 \\
1643.76\end{array}$ & $\begin{array}{l}888.95 / \\
1777.9\end{array}$ & $\begin{array}{l}5431.7 / \\
1810.56\end{array}$ & $\begin{array}{l}17900.2 \\
1626.2\end{array}$ & $\begin{array}{l}19042.2 \\
1731.11\end{array}$ & \begin{tabular}{|l|}
19621.1 \\
1783.78
\end{tabular} & 1995.93 & $13144.4 / 21907$ \\
\hline $\begin{array}{l}\text { Formation } \\
\text { Averages }\end{array}$ & $171:$ & & & 94.23 & & 1714.03 & & 1995.93 & \\
\hline
\end{tabular}

Source: Ministry of Agriculture, Makurdi Benue State, Nigeria.

Average yearly precipitation varies from $1714.0 \mathrm{~mm}$ over the Awe formation to $1995.93 \mathrm{~mm}$ over the Awgu formation. Precipitation with diameter of drop greater than $0.5 \mathrm{~mm}$ is termed rainfall and this type is responsible for erosion. The maximum size of rain drop is $6 \mathrm{~mm}$. Rainfall in the study area is usually heavy with average intensities greater than $7.5 \mathrm{~mm} / \mathrm{hr}$. The intensity ranges from $20 \mathrm{~mm} / \mathrm{hr}$ to $60 \mathrm{~mm} / \mathrm{hr}$ for heavy rains in this area .

\section{METHODOLOGY}

The climatic condition within and around the project area, essential meteorological data were obtained and analyzed. The series of data and information discussed and analyzed were obtained predominantly from the meteorological stations

Groundwater recharge was calculated using the following equations

\section{Groundwater Recharge}

Annual recharge was related to precipitation by the formula below.

$$
\mathrm{R}=\alpha(\mathrm{P}-\mathrm{Po})^{\mathrm{B}}
$$

If, $\mathrm{P} \geq \mathrm{Po}$; and

$$
\mathrm{R}=0 \text { - }
$$

Where $\quad \mathrm{R}=$ groundwater recharge

$\alpha=$ coefficient depending on soil type

Po $=$ threshold rainfall or infiltration index, whose value is assume to be $0.10 \mathrm{~cm} /$ hour whenever we estimate maximum flood for design purposes.

$\mathrm{B}=$ value equal to or close to 1 .

In the study area, $\alpha$ is considered to be 0.21 formations and 0.196 for recharge from water bodies in relation to the soil types of these areas

Table 2: Coefficient, for Various soil types

\begin{tabular}{|l|l|l|}
\hline S/NO & TYPE OF SOIL & COEFFICIENT \\
\hline 1. & Sandy soils and sandy loam & $0.17-0.25$ \\
\hline 2. & Costal alluvium and silty loam & $0.25-0.3$ \\
\hline 3. & Red soils, clayey loam, grey and brown alluvium & \\
& & 0.42 \\
\hline 4. & Black-cotton and clayey soils & $0.42-0.46$ \\
\hline 5. & Hilly soils & $0.46-0.50$ \\
\hline
\end{tabular}

Source: (Barlow 1948) 


\section{DATA PRESENTATION AND DISCUSSIONS}

The following values were obtained for each of the formations (Table 3). Ground water recharge values range from $305 \mathrm{~mm} / \mathrm{yr}$ (17\% of precipitation) at awe Formation. In the Lafia sands to $418.9 \mathrm{~mm} / \mathrm{yr}$ (21\% of precipitation ). The Lafia sandstone registers the highest amount of groundwater recharge because it consists of principally porous and clean sands. The Awe shaleshas the lowest because of the less permeability of the shales. The 17\% groundwater recharge here is recorded due to the fact that fracturing occurs in the shales and in most place the fracture intensity is high. Average yearly precipitation varies from $1714.0 \mathrm{~mm}$ over the Awe formation to $1995.93 \mathrm{~mm}$ over the Awgu formation. Precipitation with diameter of drop greater than $0.5 \mathrm{~mm}$ is termed rainfall and this type is responsible for erosion. The maximum size of rain drop is $6 \mathrm{~mm}$. Rainfall in the study area is usually heavy with average intensities greater than $7.5 \mathrm{~mm} / \mathrm{hr}$. The intensity ranges from $20 \mathrm{~mm} / \mathrm{hr}$ to $60 \mathrm{~mm} / \mathrm{hr}$ for heavy rains in this area .

Table 3: Average Groundwater Recharge in the Study Area.

\begin{tabular}{|l|c|c|c|}
\hline \multirow{2}{*}{ FORMATION } & \multicolumn{2}{|c|}{ PRECIPITATION } & \multicolumn{2}{|c|}{ GROUNDWATER } & \multirow{2}{*}{ \% OF PRECIPITATION } \\
\cline { 2 - 3 } & $\mathbf{m m} / \mathbf{y r}$ & $\mathbf{m m} / \mathbf{y r}$ & 21.0 \\
\hline Lafia & 1751.23 & 367.55 & 17.00 \\
\hline Awe & 1793.95 & 305.00 & 20.99 \\
\hline Keana & 1714.03 & 359.74 & \\
\hline & & & \\
\hline
\end{tabular}

Source: (Calculated from equation 1 Groundwater Recharge)

\section{SUMMARY AND RECOMMENDATION}

Groundwater recharge (infiltration) has serious effects on soil erosion and gullying. Infiltration influence runoff as seen in the difference in stream flow patterns in permeable and impermeable layers. Infiltration determines the moisture content in the soil. This affects the binding forces between the grains, hence influencing slumping especially at gully sites in the study. The highest growth rate of gullies occurs during the rainy season from July to October less intensive rain is recorded during August in what is called "August Break". About $70 \%-90 \%$ of annual rainfall occurs between July and September, during which there is the highest rate of gully development and soil erosion in the area. Rainfall has three main roles in relation to gullying depending on the ground and intensities diameter of the drops, and the velocity at which the drops strike the soil, viz;

(a) The kinetic energy at which the drops fall is expended on the soil particles to detach and splash them, initiating turbulence which in turn initiates flow and increases the sediment carrying capacity in fluvial erosion;

(b) Rainfall causes overland flow that develops tractive forces which detach soil particles and initiate particle movement. When the tractive forces exceed the threshold values determines by shear resistance of the soil concentrated overland flow gives rise to gully erosion while unconcentrated flow gives rise to sheet erosion; and

(c) Rainfall causes infiltration especially where there is porous/previous lithology and a good vegetation cover. Infiltration is responsible for every rampant slumping and sliding in the study area especially around gully sities. Rainfall drops strike the ground at velocities of about $305 \mathrm{~mm} / \mathrm{sc}$ and $25.4 \mathrm{~mm}$ of water over an area of $4047 \mathrm{~m}^{2}$ weighs more than $9.81 \mathrm{KN}$ (Chow, 1964). Raindrops have a very great effect on soil strength hence soil erosion.

\section{RECOMMENDATION}

Participatory approach in which governments, social/scientific groups, industrialists and individuals take part in implementation of laws on erosion control measures should be encouraged. Such an approach will lead to a consistent, adequate and effective solving of gully erosion problems in the region.

Quantitative data on all the factors that affect erosion should be studied and made available to governments, groups or individuals who are involved in solving gully erosion problems. These data should then be used in designing, constructing and maintaining good engineering structures to control runoff, floods, erosion, slumping and sliding. 


\section{REFERENCES}

1). Berry, R.D., and David, A.C. 1982. Statistical ways of analyzing erosion data.Pp 53-73 Norton and Co.

2). Chow, V.T., 1970. (Ed.) Hand Book of Applied Hydrology. McGraw Hill. New York, NY.

3). Egboka, B.C.E., and Okpoko, E.I. 1984. Gully erosion in the AguluNanka region of Anambra State Nigeria. In: Chanllenges in African Hydrology and Water Resources. Proc. Harare symp. July 1984. 335-347. IAHS Publisher no. 144.

4). Ehlich, S.P., 1989. Global change and carrying Capacity: Implications for life on earth. In: RuthsDefries and Thomas Malone (eds). Global change and our common Future: Papers from a Forum. pp. 19-27. National Academy Press.Washigton, DC.

5). $\quad$ Freeze, R.A., and Cherry, J.A. 1978. Groundwater: Prentice - Hall Inc, Enplewood Cliffs. N.J.

6). Nwabineli, E.O., 1998. Environmental degradation in Nasarawa State.Tomjos Printing Press.,Lafia. $55 \mathrm{p}$

7). Nwabineli E.O., 1999. Urban Water Pollution in Nigeria.Anthor Printing Press, Lafia. 22p

8). Offodile, M.C., 1998. Groundwater Study and Development in Nigeria.Published by Mecon Geology and Engineering Services Limited, Jos, Nigeria.455pp. $2^{\text {nd }}$ Edition.

9). Stoorvogel, J.J., and Smeling, E.M.A. 1990, Assessment of soil nutrient depletion in sub-Saharan Africa. 198-200 Winand Staring Center.Nageningen/F.A.O. Rome.

10). Sowers, P.C., 1979. Groundwater and its Associatedhydrostic Pressure. Edward Arnold Publisher Limited, London.

11). Subramenya, K., 1994. Engineering Hydrology.TotaMcgraw-Hill, New Delhi, India.

12). Terzaghi K., and Peck, R.B. 1967. Soil Mechanics in Engineering Practice. $2^{\text {nd }}$ ed. John Wiley and Sons. Inc., New York. 30p. 